\title{
The Septuagint and the Masoretic Text in the Orthodox Church(es)*
}

\author{
ALEXANDRU MIHĂILĂ $\breve{H}^{* *}$
}

In this article, I intend to survey the reception of versions of the Old Testament in the Orthodox churches, focusing on the Greek, Russian and Romanian Church, respectively. While Western biblical scholars gave precedence to the Hebrew text over the Septuagint, in the Orthodox world one can see a tension in the relationship between the two textual witnesses and sometimes, even recently, there are voices which tend to give the Septuagint total authority in the Church. Orthodox scholars in the field of Old Testament studies usually resort to the Hebrew text, but especially scholars from outside this field tend to promote the Septuagint as the Old Testament of the Orthodox Church. I shall use the argument of authority, which is improper for scientific argumentation, but it suits my research, as I try to understand the confessional positions held within Eastern Orthodoxy. Consequently, if a certain saint, acknowledged as such by a national Orthodox Church or by the entire Eastern Orthodox communion, embraces a particular view on this subject, this bears significantly on the issue.

Keywords: Orthodox Church, Bible, Septuagint, Masoretic Text, Synodal Bible.

\section{Recent positions of Romanian theologians}

I begin with an overview of the Romanian Orthodox Church, which I know better. Immediately before and especially in the aftermath of the December Revolution, the future archbishop Bartolomeu Anania worked on an important biblical project. The result, published in 2001, was a new translation of the Bible, even if Archbishop Anania called it a "revised edition according to the Septuagint". In the preface, he wrote that "the Septuagint became textus receptus [...] for the entire European East, later defined as the Orthodox Church", just as the Vulgate became textus receptus for the Catholic Church and the Masoretic Text became textus receptus for the Protestants. ${ }^{1} \mathrm{He}$ also

\footnotetext{
I want to thank Emanuel Conţac for improving my English and for his pertinent suggestions.

** Alexandru Mihăilă, University of Bucharest, Faculty of Orthodox Theology, Orthodox deacon, lecturer of Old Testament studies. E-mail address: almihaila@gmail.com

1 "Cuvânt lămuritor asupra Sfintei Scripturi”, in: Bartolomeu Valeriu Anania, arhiepiscop al Clujului, Biblia sau Sfânta Scriptură, versiune diortosită după Septuaginta, redactată și adnotată de..., București, Ed. Institutului Biblic și de Misiune al Bisericii Ortodoxe Române 2001 (Cluj-Napoca, Ed. Renașterea 2009, p. 9-10).
} 
drew attention to the "big gap" that had occurred in the Romanian biblical tradition: until 1936, Romanian Orthodox Bibles followed the Septuagint, as, for example, the Synodal Bible of 1914, but in 1936 the second Synodal Bible conformed to the Masoretic Text. His translation is meant to be a return to tradition. The only adjustment to the Hebrew Text was the spelling of anthroponyms and toponyms. ${ }^{2}$ The approach is embraced by Rev. Vasile Mihoc, the leading expert in New Testament studies among the Orthodox Romanian. ${ }^{3}$

As the interest in the Septuagint grew, more specific problems were tackled, such as the legitimacy of the Hebrew Text at all. In the afterword to Theodoret of Cyrrhus's Commentary to the Psalms, monk Filotheu (Bălan) and Florin Stuparu commented that while the Septuagint "was conceived of as the book of the Old Covenant for the whole Christendom", quoted by the Apostles in the New Testament and by all the Fathers of the Church", the Masoretic Text was "full of omissions and additions", because "the Jews at the end of the first century began to change the text of Scripture under the very careful supervision of rabbis with much hatred of the truth of Scripture, to whom the enemy [i.e. the devil] darkened their minds, so they made many mistakes". ${ }^{5}$ The Masoretic Text is not only inappropriate for Orthodox biblical study and biblical translations, but it is also demonic.

In 2004 a new project for translating the Septuagint started, this time with a professional team of classical and biblical scholars, under the patronage of the New Europe College of Bucharest. The initiator and the coordinator of the project, patrologist Cristian Bădiliță, at that time Orthodox, but then declared Greek Catholic, wrote in the preface to the first volume about the status of the Septuagint, concluding that "it became the 'official' Bible of the Church". He meant of course the "Orthodox" Church, because elsewhere he considers the Septuagint "probably 'the authoritative text of the Orthodoxy"' ". Lutheran Professor Christoph Markschies praised the translation effort but observed that the project was supported by a private institu-

2 B. V. Anania, Caiete de lucru. Atelier biblic, Cluj-Napoca, Ed. Renașterea 2003. See the review of Lucian Vasile Bîgiu, "Diortosirea Sfintei Scripturi de către Î.P.S. Bartolomeu Anania”, in: Explorări, vol. 1, p. 22-35.

3 Vasile Mihoc, "Sfânta Scriptură în Versiunea Bartolomeu Anania”, in: Tabor 5 (2011), no. 1, p. 43-49. Available online: http://www.tabor-revista.ro/pdf/10826.pdf, viewed on $04 / 16 / 2018$.

4 Teodorit episcopul Kirului, Tîlcuire a celor o sută cincizeci de psalmi ai proorocului împărat David, Sf. Mănăstire Sfinții Arhangheli - Petru Vodă, 2003, p. 530, 533.

5 Ibidem, p. 533.

6 Cristian Bădiliță et al., (coord.), Septuaginta, vol. 1, Colegiul Noua Europă, Iași, Polirom 2004, p. 15.

7 C. Bădiliță, Glafire. Nouă studii biblice și patristice, Iași, Polirom 2008, p. 232. 
tion, not by the Orthodox Church, crediting the idea that the Septuaginta is most appropriate for the Eastern Church. ${ }^{8}$

A reaction from the academic circles of the Romanian Orthodox Church to the increasing interest in the Septuagint was not long in coming. Rev. Constantin Preda, lecturer, now professor, for New Testament studies at the Orthodox Faculty of Theology in Bucharest, dedicated a study in 2006 to the inspiration of the Septuagint, that it was the Scripture of New Testament holy writers and the early Church, adding: "There is a preference that remained until today in the Orthodox Church". ${ }^{9}$ Archdeacon Ioan Ică Jr., professor of patristics and one of the most prolific modern theologians in Romania, wrote about the same issue in a special study and then in a monograph dedicated to the authoritative (canonical) writings of Orthodox thought. ${ }^{10}$ First, the importance of the Septuagint as a parallel version of the Hebrew Scripture is stressed, given the legitimate form of the Graeca veritas, along with the Hebrew veritas. ${ }^{11}$ Then Professor Ică argues for the superiority of the Septuagint over the Hebrew text, modified by the rabbis in order to avoid the Christian Messianic interpretations still found in the Septuagint. ${ }^{12}$ In this regard, I could only comment that Ică tried unsatisfactorily to combine the scientific opinion (the Septuagint and the Masoretic Text represent different versions) with the traditional view (the Masoretic text was purposely modified by rabbis). Intermingling the two explanations, the logic became weak. If the Septuagint was from the beginning different from the proto-Masoretic text, then this text diversity explains better the present form and would rule out a deliberate alternation. That is because the theory of the deliberate alternation made by rabbis presupposes the identity of the Hebrew Vorlage of the Septuagint with the proto-Masoretic one. Nevertheless, one should notice that "for the Church the authentic Old Testament is the Septuagint".

The present author, lecturer of Old Testament studies at the Faculty of Orthodox Theology in Bucharest, answered in a series articles aimed at a general readership, promoting the idea of textual diversity as being assumed

\footnotetext{
8 Christoph Markschies, "Die Septuaginta als Bibel der Kirche? Beobachtungen aus Vergangenheit und Gegenwart”, in: Reinhard G. Kratz, Bernhard Neuschäfer (eds.), Die Göttinger Septuaginta. Ein editorisches Jahrhundertprojekt, Abhandlungen der Akademie der Wissenschaften zu Göttingen NF 22, Berlin, De Gruyter 2013, p. 135-154.

9 Constantin Preda, “Inspirația Septuagintei din perspectivă hermeneutică”, in: Studii Teologice, III series, 2 (2/2006), p. 37-59 (here p. 58).

10 Ioan Ică jr, "Înapoi la Septuaginta”, in: Tabor 1 (2008), no. 11, p. 5-25, reprinted in: Ioan Ică Jr., Canonul Ortodoxiei, vol. 1, Sibiu, Deisis / București, Stavropoleos 2008, p. 142-177.

11 Ibidem, p. 173.

12 Ibidem, p. 175-176.
} 
by Church Fathers such as St. Basil the Great and St. John Chrysostom. The slogan for Orthodox biblical studies should be, I argued, "back to Hexapla", not "back to the Septuagint" as Professor Ică entitled his study. ${ }^{13}$

As expected, the problem became the very subject of $\mathrm{PhD}$ theses. Rev. Anton Savelovici wrote a $\mathrm{PhD}$ thesis in dogmatics, under the supervision of Professor Ică Jr.'s father, Rev. Ioan Ică Sr.. The argumentation is mostly confessional, although the author never argues for the exclusiveness of the Septuagint. He defends the idea that the Septuagint must be reestablished as the inspired Old Testament of the Orthodox Church and accepts at the same time the fact that the Hebrew text (the Masoretic Text) might be included into Orthodox biblical studies, but with the proviso that it suffered Jewish deformations against the Christians; "the superiority of the Septuagint facing the Masoretic Text is unquestionable". ${ }^{14}$

This problematic echoed also in popular Orthodox books, such as an Orthodox best-seller written by a talented monk from the Republic of Moldova, Father Savatie Baștovoi. ${ }^{15}$

Before moving on to the next chapter, I summarize the principal arguments in favor of the exclusiveness of the Septuagint:

- the Septuagint is older than the Masoretic Text;

- the Septuagint is inspired (a conception that started with Philo of Alexandria);

- $\quad$ the Holy Apostles and New Testament authors used the Septuagint;

- the Fathers of the Church quoted the Septuagint;

- the rabbis modified the Masoretic Text in order to eliminate the Messianic prophecies concerning Jesus Christ;

- the Septuagint is the official version of the Orthodox Church.

Two further observations should be added. In the West a rediscovery of the Septuagint had already emerged in the 50's and the 60's, especially in Dominican circles, among biblical scholars and patrologists. ${ }^{16}$ In 1986,

13 Alexandru Mihăilă, "La ce bun textul masoretic?”, Ziarul Lumina, 25 March 2010; "Înapoi la Hexapla (I)", Ziarul Lumina, 6 July 2011; "Înapoi la Hexapla”, Ziarul Lumina, 13 July 2011. Reprinted in: (Ne)lămuriri din Vechiul Testament. Mici comentarii la mari texte, București, Nemira 2011, p. 36-57.

14 Anton Savelovici, Textul Sfintei Scripturi în Biserica Ortodoxă Română, Târgoviște, Valahia University Press / Ed. Bibliotheca 2012, p. 39-40. The final quotation is from p. 68.

15 Savatie Baștovoi, Audiența la un demon mut. Roman istorico-fantastic despre soarta Bisericii in vremurile de pe urmă, București, Cathisma 2009, p. 101-103.

16 Pierre Benoit, "La Septante est-elle inspirée?”, in: Nikolaus Adler (ed.), Vom Wort des Lebens. Festschrift Max Meinertz, Münster, Aschendorffsche Verlagsbuchhandlung 1951, p. 41-49, reprinted in: Pierre Benoit, Exégèse et Théologie, volume 1, Paris, Éd. du Cerf 1961, p. 3-12; P. Benoit, "L'inspiration des Septante d'après les Pères", in: L'homme devant Dieu. 
Marguerite Harl started the French translation with patristic notes of the Septuagint (La Bible d'Alexandrie), that continues up to the present and has massively influenced the Romanian translation subsidized by the New Europe College. New scholarship, such as Mogens Müller's study about the Septuagint as the "the first" and "the true" Bible of the Church, was quoted by professor Ică Jr. ${ }^{17}$

Secondly, these steps toward what one might call sola Septuaginta in the Orthodox Church are taken not by Old Testament Orthodox scholars, which can verify against the biblical text the relationship between the Septuagint and the Hebrew text, even in the exegesis of the Church Fathers. Most of the champions of the exclusiveness of the Greek version came from the field of dogmatics.

\section{Current Bible editions in the Orthodox Churches}

A legitimate contribution to the discussion over the places held by the Septuagint and the Hebrew Text in Orthodoxy consists in studying the present Bible editions of the Orthodox churches. For the purposes of the present paper, I shall refer only to the Greek, Russian and Romanian Churches. Nevertheless, their geographical extension is actually overwhelming in contemporary Orthodoxy.

Let us begin with the Greek Orthodox Church. Surprisingly, the first Old Testament edition sponsored by the Church dates from 1997, with multiple reprints. ${ }^{18}$ It was published by the Apostoliki Diakonia publishing house, owned by the Greek Church. But it is important to notice that the Greek Church published only the Septuagint and never a translation in Modern Greek. The preface signed by Metropolitan Petros (Daktylidis) of Chrystoupolis (†2012), head of the Greek Bible Society, states the following:

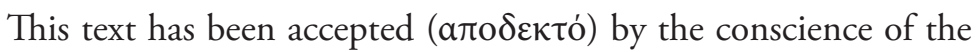
ecclesiastical body and has been the basis for theological discussions, and hence the decisions of the local and ecumenical Synods, as well as the repeated approval ( $\pi \mathrm{o} \lambda \lambda \alpha \pi \lambda \dot{\eta} \dot{\varepsilon} \gamma \kappa \rho เ \sigma \eta)$ of the

Mélanges offerts au père Henri de Lubac, Theologie 56, volume 1, Paris, Aubier 1963, p. 169187; Paul Auvray, "Comment se pose le problème de l'inspiration des Septante", in: Revue Biblique 59 (1952), p. 321-336.

17 Mogens Müller, The First Bible of the Church: A Plea for the Septuagint, Journal for the Study of the Old Testament. Supplement Series 206, Sheffield, Sheffield Academic Press 1996, p. 121: "The urgent question, still unanswered, is therefore whether Graeca veritas is in fact, in a historical perspective, the true Bible of the Church, and therefore also the obvious basis for all translations of the Old Testament as part of the Christian Bible".

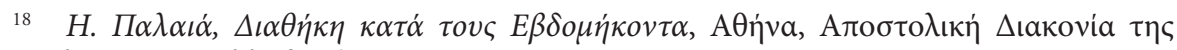

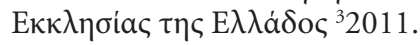


Church of Greece and the Ecumenical Patriarchate of Constantinople. [...] The translation of the Seventy was for the Church the Apostolic Bible, to which both the Lord and His disciples refer. [...] It enjoys divine authority and prestige as the Bible of the

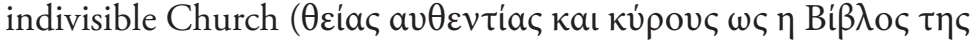

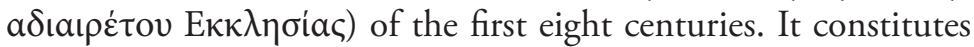

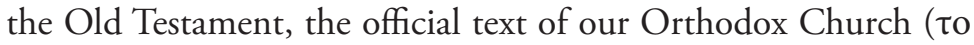

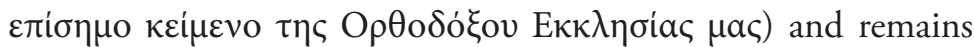

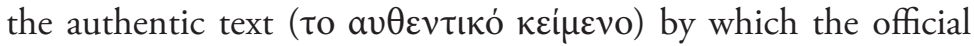
translations of the Old Testament of the other sister Orthodox Churches were made; it was the divine instrument of pre-Christ evangelism and was the basis of Orthodox Theology.

At first sight it would seem that things are clear. An edition endorsed by the Greek Orthodox Church deemed the Septuagint "the accepted" and "the official text" for "our" Orthodox Church, having "repeated approval" of the Church of Greece and the Ecumenical Patriarchate of Constantinople. But what does "our" stand for? Is the Septuagint "the official" Old Testament version only for the Greek Church or for the entire Orthodoxy? Another question can refer to the "approval": Is there a synodal decree that the Septuagint is the "official" and "authentic" text?

We may ask what does "official" mean? In the Roman Catholic Church, there are three categories in which biblical editions can be placed. It is interesting to take this into account, because it can also help us to better understand what "official" could mean for the Orthodox Church. First there are papal editions, called "typical". For example, the Council of Trent approved the authority of the Vulgate in 1546, considering it as "authentic (authentica)" and stating that this old edition was "approved" by the Church. ${ }^{19}$ As a result, in 1590, under Pope Sixtus V, the Sistine Vulgate was published. A revised edition appeared under Pope Clement VIII in 1592, the so-called Clementine Vulgate, that with subsequent corrections replaced the Sistine Vulgate and functioned as an official edition of the Catholic Church until it was corrected in its turn as Nova Vulgata in 1979 under Pope John Paul II (a new edition in 1986). ${ }^{20}$ It is worth noting that the edition is called "typical" (editio typica and for the 1986 edition editio typica altera). In the prefacing apostolic Constitution, it is mentioned that the pope declares and promulgates it as such. Surely, we are dealing here with an "official" edition, approved by the leader of the Roman Church and accepted as such by the

19 Hubert Jedin, A History of the Council of Trent, vol. 2, London, Th. Nelson 1961, p. 92.

20 http://www.vatican.va/archive/bible/nova_vulgata/documents/nova-vulgata_index_lt.html, viewed on $04 / 16 / 2018$. 
entire body of the Church. As a second category, there are biblical editions approved by the Catholic Church through the formula "nothing stands in the way" (nihil obstat), regardless whether the printing house belongs or not to the Catholic Church. It is a church endorsement certifying that there is nothing in the book that might be in conflict with the Catholic faith. For example, the famous Jerusalem Bible from 1956, with its subsequent revisions, has this kind of approval. There is also a third category for the Catholics: ecumenical editions, on which not only Catholics, but also non-Catholic scholars worked, such as the well-known Ecumenical Translation of the Bible (TOB) in 1975 (with the latest revision from 2010). The ecumenical translations do not have the nibil obstat approval.

Now let us return to the situation in the Greek Orthodox Church. There is no equivalent to the first category of Bible edition from the Catholics, because there is no synodal (the equivalent to papal) decision on the status of the Septuagint. The Apostoliki Diakonia edition seems to be closer to the second category.

The first Orthodox printing of the Old Testament dated from 1687 in Venice, but it was not an ecclesiastic enterprise, as it was supported by Wallachian voivode S,erban Cantacuzino. Under the Ottoman rule, the Greek Church was not allowed to publish ecclesiastic books at all. This was possible only after the war of independence (1821-1832). The first Old Testament in Greek published by an Orthodox church dates from 1821 and was printed by the Moscow Patriarchate. It is interesting to note that the text of the Septuagint was taken from Grabbe's polyglot, which follows the Codex Alexandrinus. The first edition issued in Greece dates from 1843-1850, a reprint of the Moscow Bible. Other editions followed (1928, 1935, 1950, 1991), supported by the Zoi brotherhood with the blessing of the Church. ${ }^{21}$

Unlike the Moscow Bible of 1821 that contained the Codex Alexandrinus, the edition published by Apostoliki Diakonia opted for the Codex Vaticanus, a solution inherited from the previous Zoi editions, as one can see in the places where there are important differences between manuscripts.

\begin{tabular}{|c|c|}
\hline $\begin{array}{l}\text { Moscow Bible } \\
\approx \text { Codex Alex }\end{array}$ & $\begin{array}{c}\text { Apostoliki Diakonia Septuagint } \\
\approx \text { Codex Vaticanus }\end{array}$ \\
\hline 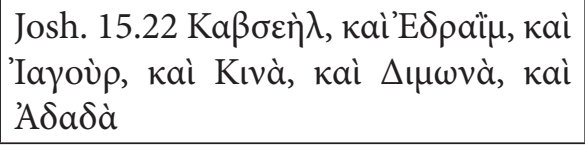 & 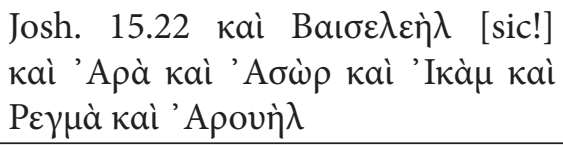 \\
\hline
\end{tabular}

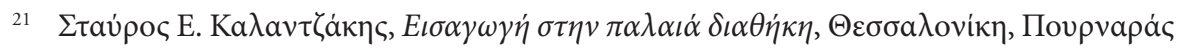
2006, p. 208-209. 
Judg. 6.11 Kaì $\tilde{\eta} \lambda \theta \varepsilon v$ ä $\gamma \gamma \varepsilon \lambda o \varsigma$

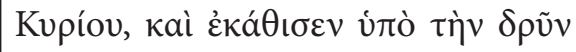

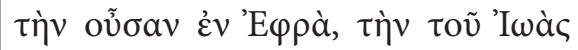

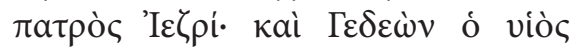

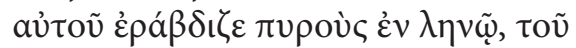

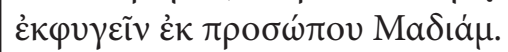

Judg. 6.11 Kaì ñर $\theta \varepsilon v$ ä $\gamma \gamma \varepsilon \lambda o \varsigma$ Kupíov

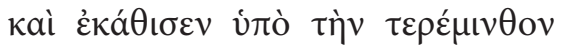

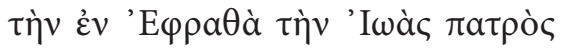

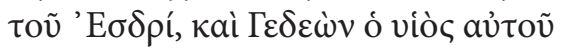

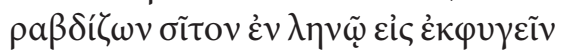

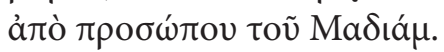

In 1997 another event marked the biblical history of the Greek Orthodox Church: the first edition of the Bible in Modern Greek approved by the Greek Orthodox Church. This happened after tremendous opposition from the Church. ${ }^{22}$ After the Evangelika riot in November 1901, a popular reaction to Palli's Modern Greek translation of the Gospel of Matthew, any attempt to translate the Bible into Modern Greek without ecclesiastic permission was explicitly forbidden by the Greek constitution in 1911 and the interdiction was repeated in 1927, 1952 and 1975. The Modern Greek translation of $1997^{23}$ was not published by the Greek Church, but by the Greek Bible Society, with the letter of recommendation from the Church (photocopied as such on one of the first pages). Although not expressis verbis, it is basically a blessing on behalf of the Church. See, for example, the statement on the Greek Bible Society's website: "with the blessing and approval

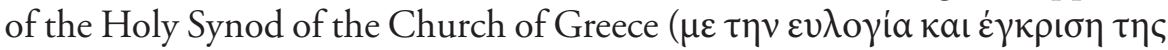

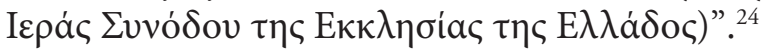

The publisher, the Greek Bible Society, explains that "the basis for the translation of the Old Testament consists in the Hebrew original text". Already in 1968, Professor V. Vellas of Athens translated 22 Old Testament books into the Modern purist Greek (katarevousa) using the Hebrew text. After Vellas' death in 1969, the project was continued by a team of professors led by I. Oikonomou, including N. Olympiou, N. Papadopoulos, P. Simotas and V. Tsakonas. Meanwhile, in 1976 Greece officially adopted the Modern spoken Greek (dimotiki) and the translation was adapted by professors V. Tsakonas and M. Konstantinou, helped by a philologist, A. Chiotellis.

\footnotetext{
22 Nomikos Michael Vaporis, Translating the Scripture into Modern Greek, Brookline, Massachussetts, Holy Cross Orthodox Press 1994 (revision of the PhD thesis: The controversy of the translation of the Scriptures into modern Greek and its effects, 1818-1843, Columbia University, 1970); Dimitris Livanios, "«In the Beginning Was the Word»: Orthodoxy and Bible Translation into Modern Greek (16th-19th Centuries)", in: Mediterranean Chronicle 4 (2014), p. 101-120.

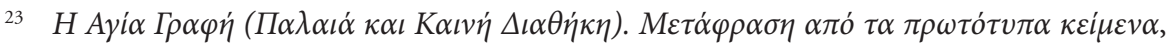

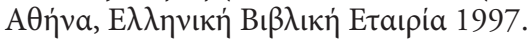

24 http://www.greekbibles.org/index.php?id_product=1\&controller=product\&id_lang=7, viewed on $04 / 16 / 2018$.
} 
For the present study the letter of recommendation from the Church, unfortunately with an indecipherable signature at the bottom, is very instructive:

I was glad to receive the translation of the Old Testament from the laborious work of many specialized scholars, from the original Hebrew text into Greek, for which the Holy Mother, the Church of Christ, congratulates those who have accomplished it and worked it, seeing it as one that can help the godly people who have scientific preoccupations for knowing, understanding, and acquaint-

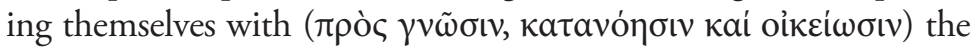

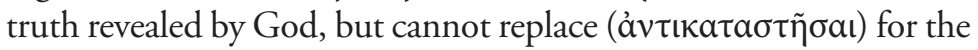

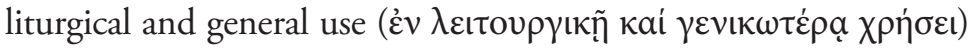
in our Holy Orthodox Church the translation of the Seventy.

Because it followed the Hebrew Text and not the Septuagint, this edition is meant to represent only an auxiliary in biblical instruction. It cannot replace the Septuagint, which enjoys a special status, being "generally" used in the Church. It is also important to note that the Orthodox Church blessed a translation from the Hebrew Text.

The Russian Orthodox Church finds herself in a similar position. Traditionally, the Russian Church draws its lections for the liturgical services from the Slavonic Bible based on the Septuagint, but since 1876 she also has a Synodal Bible translated into the vernacular, "with the blessing of the Holy Patriarch of Moscow and of all Russia"25. As in Greece, the Russian translation was only completed after long debates, compared by Stephen Batalden with real wars. ${ }^{26}$ With the help of St. Philaret (Drozdov), Metropolitan of Moscow, the Russian Synodal Bible followed mainly the Hebrew Text, but with numerous influences from the Septuagint, especially in the passages which are important in establishing certain dogmas (such as дева "virgin" in Isa. 7:14). About twothirds of the Hebrew text was translated by a Hebrew scholar, Professor Daniil Khvolson of the St. Petersburg Faculty of Oriental Studies.

Unlike the Greek and the Russian Orthodox Churches, the Romanian Orthodox Church doesn't have to grapple with diglossia, therefore it is all the more significant that the current Romanian Synodal Bible 2015²7, a

25 Библиа. Книги Сбящзенного Писания Ветхого и Нового Завета, Москва, Издательство Московской Патриархии 2013.

26 Stephen K. Batalden, Russian Bible Wars: Modern Scriptural Translation and Cultural Authority, Cambridge, Cambridge University Press 2013; Б.А. Тихомиров, "Начало истории русского перевода Библии и Российское библейское общество”, in: Христианское чтение 28 (2007), р. 111-146.

27 Biblia sau Sfânta Scriptură, București, Ed. Institutului Biblic și de Misiune Ortodoxă 2015. 
revised reprint of the second Synodal Bible published in 1936, "printed with the blessing" of the patriarch and "with the approval of the Holy Synod", combines the Hebrew Text and the Septuagint, much like the Russian translation does. The second, the third and the fourth Synodal editions (1936, 1944 and 1968) were undertaken as a "preliminary edition" (ediție de probă), a possible indication that the combination of the Septuagint with the Hebrew text was still perceived as problematic. It is also worth noting that in the past the Romanian and the Russian Synodal Bibles were also printed by the national Bible Societies, but under the same terms, i.e. the blessing of the patriarch and/or the synod.

Setting aside Anania's translation, which was only issued once by the official printing house of the Church, the only other Orthodox Church which supported a translation of the Septuagint is, as far as I know, in America. St. Athanasius Academy of Orthodox Theology under the Antiochian Orthodox Christian Archdiocese of North America (with an autonomous status under the jurisdiction of the Greek Orthodox Church of Antioch) published The Orthodox Study Bible in 2008. ${ }^{28}$ In the preface it says: "Though the Orthodox Church has never officially committed itself to a single text and list of the Old Testament books, it has traditionally used the Greek Old Testament of the Septuagint (LXX)". But the translation could not consistently follow the Septuagint: as in the case of Metropolitan Bartholomew (Anania), the names are taken from the Hebrew text. For example, in $1 \mathrm{Kgs.}$ (1 Sam.) 4.2 etc. å $\lambda \lambda$ ó $\varphi v \lambda o$ is translated "Philistines" as in the Hebrew Text (as opposed to "allophyles" in the New English Translation of the Septuagint). The toponyms in the book of Joshua are transcribed according to the Hebrew text and not to the Septuagint.

We can now reach a preliminary conclusion. The Orthodox editions of the Old Testament never had the general approval of the Church as the Catholic "typical edition". Instead they had the approval (the blessing) of the Church for local issuances and under specific circumstances. The Church pays respect to the Hebrew Text, but at the same time tries to keep it at bay. The Greek Orthodox Church promotes the Septuagint, switching from the Codex Alexandrinus to the Vaticanus, without explicitly canonizing a particular manuscript tradition. The role of the Hebrew text is acknowledged for biblical instruction, a clear task for diglottic Churches, such as the Greek and the Russian ones, but hard to manage by the Romanian Church, which considered instead the combination of the Septuagint and the Hebrew text as "preliminary edition" until further considerations.

\footnotetext{
28 "Introduction to the Orthodox Study Bible", in: The Orthodox Study Bible, Nashville,
} Thomas Nelson 2008. 


\section{Septuagint vs. (proto-) Masoretic Text during the antiquity}

In order to understand contemporary positions in Orthodoxy about the Septuagint and the Hebrew text, it is important to trace some of the ideas back to their origin in the Early Church.

It is to be remembered that the Masoretic Text is the standardized Hebrew text transmitted by the Masorets, especially by the Tiberias scholars from the family of Aharon ben Asher. It is a late text, the oldest manuscripts dating from the end of the $9^{\text {th }}$ century and especially from the $10^{\text {th }}$. It is true that there is a small fragment from the $7^{\text {th }}$ century, but the oldest completely preserved manuscript is that of Sankt Petersburg dating from 1009/1008, which is used for present critical editions (for example, the revised edition of the Biblia Hebraica Stuttgartensia). It follows that the Church could use it only later, mostly since the second millennium, but if we refer to the standardized proto-Masoretic Hebrew text that emerged after the destruction of the Temple in Jerusalem, we may say that the Church appealed to the Hebrew text much earlier.

\section{New Testament quotations of the Old Testament}

A proper case study for the discussion is to answer the question concerning the nature of the Old Testament text quoted in the New Testament. The methodology used to identify a quotation may vary from author to author, but the general view is compelling. From about 312 cases, most of them being identical or similar in both textual witnesses, $50 \mathrm{New}$ Testament quotations follow the peculiar wording of the Septuagint (actually only 22 of them being completely different), while 33 quotations follow the wording of the Masoretic Text (or/and Proto-Theodotion). ${ }^{29}$ Therefore, the claim that the Old Testament of the early Church was only the Septuagint is not supported by facts. But what does this adherence to the wording of the Masoretic Text mean? Did the New Testament authors really quote the proto-Masoretic text by translating it into Greek?

Recent studies have shown that New Testament quotations which differ from the Septuagint are not actually drawn from the proto-Masoretic text, but from Greek revisions of the Septuagint according to the proto-Masoretic text, especially the kaige-Theodotion (or proto-Theodotion) revision. Emanuel Tov, a renowned expert in this field, explained: "There is no reason to assume that Matthew or Paul themselves produced these literal translations, because the agreement between the quotations and known revisions

29 Gleason L. Arche, Gregory Chirichigno, Old Testament Quotations in the New Testament, Chicago, Moody Press 1983, p. xxv-xxxii. 
such as kaige-Theodotion are too obvious" ${ }^{30}$ Recent studies have indeed endorsed this conclusion. ${ }^{31}$

But another secondary question should be wrestled with: Is proto-Theodotion part of revision stages of the Septuagint? Maarten Menken, who studied the Old Testament quotations in the Gospel of Matthew, is inclined to answer yes: "The textual form of this continuous biblical text is best described as a revised LXX". ${ }^{32}$ However, I think that the term "revised Septuagint" used by Menken is misleading. It would be better to speak about a revised Greek text. It was rather the proto-Masoretic text, not the Septuagint, that proto-Theodotion actually revised.

Therefore, one can argue that the New Testament authors didn't quote directly from the proto-Masoretic text but were consciously influenced by it. The Old Testament quoted in the New Testament is mainly the Septuagint and in some particular cases translations based upon proto-Masoretic text, such as proto-Theodotion. This means that the Septuagint is not the only Old Testament text quoted in the New Testament (sola Septuaginta) and that the influence of the proto-Masoretic text is not extensive but remains significant.

\section{St. Justin Martyr's view on the Hebrew Text}

In the mid-second century, St Justin Martyr ( $† 165)$ wrote a learned disputation with a Jew, Dialogue with Trypho. ${ }^{33} \mathrm{He}$ is the first Christian writer who accused Jewish teachers of distorting the Holy Scripture, especially in the famous Isaianic prophecy concerning the Virgin who will conceive, Isa. $7.14(68.8 ; 84.3)$.

I would also have you know that from the version composed by those elders at the court of Ptolemy, they (i.e. your teachers) have deleted entire passages in which it is clearly indicated that the cru-

30 Emanuel Tov, Textual Criticism of the Hebrew Bible, Qumran, Septuagint: Collected Essays, vol. 3, Supplements to Vetus Testamentum 167, Leiden - Boston, Brill 2014, p. 459-460.

31 Aline Canellis, "Introduction", in: Jérôme, Préfaces aux livres de la Bible, Sources Chrétiennes 592, Paris, Ed. du Cerf 2017, p. 107; she quotes from: U. Rüsen-Weinhold, Der Septuagintapsalter im Neuen Testament, Neukirchen, 2004, p. 2-13; Gilles Dorival, "L'Ancien Testament du Nouveau Testament", in: Christian-Bernard Amphoux (coord.), Manuel de critique textuelle du Nouveau Testament, Bruxelles, 2014, p. 195-210; Eugen J. Pentiuc, The Old Testament in Eastern Orthodox Tradition, Oxford - New York, Oxford University Press 2014, p. 74.

32 Maarten J.J. Menken, Matthew's Bible: The Old Testament Text of the Evangelist, Bibliotheca Ephemeridum Theologicarum Lovaniensium 173, Leuven, Leuven University PressPeeters 2004, p. 280.

33 Selection from the Fathers of the Church, volume 3: Dialogue with Trypho, transl. by Thomas B. Falls, revised by Thomas P. Halton, Washington, Catholic University of America Press 2012. 
cified one was foretold as God and man, and as about to suffer death on the cross (71.2).

St. Justin gave some examples of passages allegedly omitted by the Jewish teachers: the law of the Passover from Esdras (quoted also by Eusebius and Lactantius, probably a Jewish-Christian midrash to the canonical book of Ezra), a reference to the sacrificial lamb in Jeremiah 11 (while also mentioning that the passage was found in a few Jewish copies), a text about the Lord descending to preach to the dead (an unknown passage attributed to prophet Jeremiah, quoted also by St. Irenaeus who attributed it both to Isaiah and Jeremiah), the phrase "from the wood" of Psalm 96 (72-73); the reading "until he comes for whom it is laid up" in the Septuagint version of Gen. 49.10 instead of "until the things laid up for him come" from the Hebrew text in the prophecy about the scepter from Judah (120.4).

Sometimes the difference is not considered problematic. St. Justin quoted Psalm 82 "as translated by you yourselves", but also "in the Septuagint translation" (124.2-3), concluding: "hold whatever interpretation of the psalm you please" (124.4). The same openness toward the Hebrew text, when it does not entail a particular dogmatic consequence, is found elsewhere:

My friends, I will now quote Scripture according to the Septuagint version. For, when I cited those passages as you read them, I was trying to ascertain your frame of mind. In quoting the passage [...] I added the words of the Septuagint, "Let us take away the Just One, for he is distasteful to us». Yet, at the beginning of our discussion I cited it according to your version (i.e. the Hebrew text): "Let us bind the Just One, for he is distasteful to us" (137.3). ${ }^{34}$

Deut. 32.7-9 is also quoted according to the Hebrew Text and according to the Septuagint; "But, since here again my argument is in no way weakened by this difference, I have given your exegesis" (131.1). To put it simply, St. Justin Martyr used mostly the Septuagint, but he didn't reject the Hebrew version, except in a few cases where he believed that the rabbis had deliberately excised the Christian Messianic meaning.

He exaggerates about the rabbinical distortion of the text, but we can explain this as a polemical strategy. In fact, he is mistaken in certain cases, such as the words "from the wood", which are missing from all the Septuagint manuscripts of Psalm 96 (95 LXX). Most probably St. Justin quoted the

34 St. Justin is mistaken in this particular case: "let us bind" is found in the Septuagint, while "let us take away" is influenced by Prov. 1.12. 
passage not directly from the biblical text, but from a collection of testimonies or from a Psalter which included some glosses. ${ }^{35}$

\section{Origen and the ecclesiastical text(s) of the Old Testament}

As already stated in the introduction, I try to identify the confessional arguments in the discussion. That is why I use the arguments of authority, seeking mostly authoritative figures in the history of the Church.

From the point of view of the Orthodox Church Origen is a heretic. Nevertheless, his correspondence with Julius Africanus is very important for our discussion because Origen responded to Africanus' query whether the story of Susanna was written or not in Hebrew. According to Origen, the Jews suppressed some inconvenient passages from the Scripture and the ultimate criterion for the canonicity of a biblical book is not the synagogue, but the Church. ${ }^{36}$

But Origen's Hexapla influenced significantly the formation of an Ecclesiastical text of the Bible. It is indeed very interesting what sort of text the Church preferred from among the existing manuscripts. Some OT books have a special history, apart from the Septuagint. For example, the early Church preferred the translation of Theodotion to the Septuagint for the book of prophet Daniel. Old Greek Daniel is preserved only in manuscript 967 of the Chester Beatty papyri (third cent. A.D.) and in the Septuagint column of Origen's Hexapla. ${ }^{37}$

The book of Job is another case in point; its Greek manuscripts evidence a mixed textual tradition (the so-called Ecclesiastical text), produced by Origen in his Hexapla: because the original Septuagint is about one-sixth shorter than the Hebrew version of Job, Origen inserted the missing text from Theodotion, marking it at the beginning with an asterisk and at the end with a metobelus. ${ }^{38}$ This approach led him sometimes to insert by mistake the same text twice, as in Job 18.9. ${ }^{39}$

Important saints of the Eastern Church used Origen's Hexapla in their commentaries and treatises. It is known that St. Basil the Great, St. Gregory

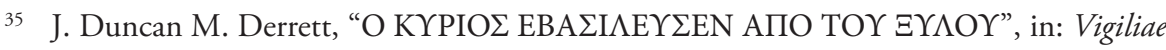
Christianae 43 (1989), p. 378-392 (especially p. 385).

36 Edmon L. Gallagher, Hebrew Scripture in Patristic Biblical Theory: Canon, Language, Text, Supplements to Vigiliae Christianae 114, Leiden - Boston, Brill 2012, p. 63-85.

37 Michael B. Shepherd, Daniel in the Context of the Hebrew Bible, Studies in Biblical Literature 123, New York, Peter Lang 2009, p. 68.

38 Peter John Gentry, The Asterisked Materials in the Greek Job, Society of Biblical Literature. Septuagint and Cognate Studies Series 38, Atlanta, Scholars Press 1995.

39 Claude E. Cox, "Job: To the Reader", in: Albert Pietersma, Benjamin G. Wright (eds.), A New English Translation of the Septuagint and the Other Greek Translations Traditionally Included under That Title, New York - Oxford, Oxford University Press 2007, p. 668-669. 
of Nazianzus and St. John Chrysostom used mostly the Septuagint, which

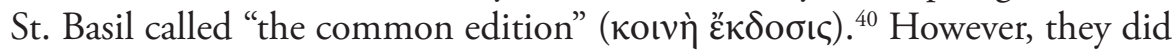
turn to the other translations (Aquila, Symmachus and Theodotion) based on the proto-Masoretic text. By the mid-sixth century the Septuagint became the standard edition, as attested by Novella 146 (13 February 553) of Emperor Justinian, who permitted the use of Aquila's translations in the synagogue, "although the author is of an alien race and his translation shows not inconsiderable differences from that of the Septuagint". ${ }^{41}$

\section{St. Jerome's controversy with St. Augustine over the Vulgate}

St. Jerome's correspondence with St. Augustine ${ }^{42}$ and his prologues to the books of the Bible bear significantly on the complexity of the problem. Far from being convinced from the beginning about the Hebraica veritas, St. Jerome was in fact the first who used the term Graeca veritas (Prologue to the Gospels 1). ${ }^{43}$ In Bethlehem he translated the Old Testament from the Septuagint between 386 and 389, but then he began afresh again, working from the Hebrew text, between 390 and 405. It is safe to assume that he converted to the Hebraica veritas only after dealing first with the Greek version and gaining first-hand experience about the inadequacy of the undertaking.

Certainly, if you are incredulous, read the Greek and Latin books and compare (them) with these little works, and wherever you will see among them to differ, ask any one of the Hebrews, in whom you might place better faith (cui magis accomodare debeas fidem $)^{44}$ (Prologue to Samuel and Kings 3).

For him the Hebrew text became the standard in all cases where there was a difference between the textual witnesses. As a Christian author, St. Jerome is bold enough to consider his translation superior to the Septuagint, a product of the Jewish milieu. ${ }^{45}$

40 A. Mihăilă, "Introducere", in: Sf. Vasile cel Mare, Comentariu la cartea profetului Isaia, Părinți și Scriitori Bisericești (seria nouă) 2, București, Basilica 2009, p. 11.

${ }^{41}$ Sidney Jellicoe, The Septuagint and Modern Study, Winona Lake, Indiana, Eisenbrauns 1993 (reprint of 1978), p. 77.

42 Dragoș Mîrșanu, "From Greek Authority to Hebrew Verity and Back: The Question of the Source Texts of the Latin Old Testament in the Correspondence between Saints Augustine and Jerome", in: Hermeneia 17 (2016), p. 163-174.

43 A. Canellis, "Introduction", p. 470-471, see p. 103.

44 English translation by Kevin P. Edgecomb, 2006 - http://www.tertullian.org/fathers/ jerome_preface_kings.htm. See Jérôme, Préfaces aux livres de la Bible, Sources Chrétiennes 592, p. 334-335.

45 A. Canellis, "Introduction", p. 107-108. 
Moreover, he says that Origen's effort to "mix the translation of Theodotion to the ancient edition" gave him an impetus to further study. He became convinced that the Apostles and the Evangelists drew their quotations from the Hebrew text. ${ }^{46}$ There are many things from the Old Testament missing in the Septuagint: "Out of Egypt I have called My Son" (Mt. 2.15), "For He shall be called a Nazarene" (Mt. 2.23), "They will look on Him whom they have pierced" (Jn. 19.37), "Rivers of living waters shall flow from his belly" (Jn. 7.38) and "Things which no eye has seen, nor ear heard, nor has arisen in the heart of man, which God has prepared for those loving Him" (1 Cor. 2.9) "and many others which require a proper context (proprium $\sigma u ́ v \tau \alpha \gamma \mu \alpha$ desiderant)". Jerome continues: "Therefore let us ask them where these are written, and when they are unable to say, we may produce them from the Hebrew books" (Prologue to the Pentateuch 2) ${ }^{47}$.

In 384/385 St. Augustine requested a few explanations in a letter sent to Jerome (Augustine, Ep. 28). Contrary to Jerome, he overestimates the Septuagint and the experience of its translators:

I would be very surprised if anything could still be found in the Hebrew texts which had escaped the notice of all those translators who were such experts in that language. I say nothing of the Seventy, for I would not dare to any kind of decisive answer to the question of whether they possessed a greater harmony of wisdom or of inspiration that one man could have, but I do think that their work should without doubt be accorded preeminent authority in this field (praeeminentem auctoritatem) (Ep. 28.2).

Having received no answer, in 403 Augustine reopened the question, sending another letter (Ep. 71) with a copy of his former letter. He expresses concerns regarding Jerome's translation based on the Hebrew text, which has already stirred controversy. In 405 Jerome answers (Ep. 112 ${ }^{48}$ :

I am surprised that you are not reading the Septuagint in the original form as it was produced by the Seventy, but in an edition corrected, or corrupted, by Origen using daggers and asterisks... Do you wish to be a true admirer of the Septuagint? Then you should not read what is preceded by an asterisk - in fact you should delete such passages from your copy, to prove yourself to be a supporter of the

\footnotetext{
46 Ibidem, p. 106-107.
}

47 English translation by Kevin P. Edgecomb, 2006 - http://www.tertullian.org/fathers/ jerome_preface_genesis.htm. See Jérôme, Préfaces aux livres de la Bible, Sources Chrétiennes 592, p. 304-307.

48 "Letter LXXV" in St. Augustine's letters, in: Philip Schaff (ed.), Nicene and Post-Nicene Fathers, first series, vol. 1, Buffalo, The Christian Literature Company 1886, p. 333-343. 
ancient translators. But if you were to do this, you would be forced to condemn all churches libraries for only one or two copies are to be found which do not contain these passages (Ep. 112.19-20).

St. Jerome refers to the fact that especially after Origen the Septuagint was not pure anylonger, but under its name a composite text circulated among the Christian churches. With the final answer (Augustine, Ep. 82), the correspondence between St. Augustine and St. Jerome (both canonized by the Orthodox Church), far from resolving the problem, is testimony to the tension in the early Church between the preeminence of the Graeca veritas and that of the Hebraica veritas.

Sometimes, the Orthodox tend to judge the Vulgate, the canonized Bible of the Catholic Church, separately from St. Jerome. As we shall see, St. Jerome himself was accused of poor translation skills and ignorance. But he is canonized in the Greek Orthodox calendar (with feast day on June 15, together with St. Augustine) and his liturgical celebration was composed by a certain $\mathrm{Ni}$ phon the Hagiorite and published in Athens in $1925 .{ }^{49}$ While he is a newcomer in the Orthodox calendar (a sign of his controversial reception in the East), his title of hosios doesn't suggest a lesser degree of holiness as the title given in the Romanian calendar, fericit ("blessed" or "beatified"), might imply. Nevertheless, the Orthodox Church does not differentiate between two stages of holiness, "blessed" and "saint", as the Catholic Church does (beatus and sanctus).

\section{Peshitta}

Peshitta is the name of the Syriac Bible translation similar to the Vulgate. Sebastian Brock estimates for the translation of the Old Testament the period between the end of the $1^{\text {st }}$ century and the beginning of the $3^{\text {rd }}$ century A.D. (generally the $2^{\text {nd }}$ century), although the oldest preserved manuscript dates from the $5^{\text {th }}$ and $6^{\text {th }}$ centuries A.D. Brock considers that the translation of the Old Testament was made after the proto-Masoretic text (including the book of Jesus ben Sira) ${ }^{50}$ and only the books specific to the Septuagint were translated from Greek. A recent study by Weitzman demonstrated convincingly that the Masoretic Text and Peshitta have in fact a common textual ancestor and that Peshitta, although much closer to the Masoretic Text and not to Septuagint, differs in some cases from the Masoretic Text. ${ }^{51}$ There was

49 http://www.saint.gr/1860/saint.aspx, viewed on 04/16/2018.

50 Sebastian P. Brock, The Bible in the Syriac Tradition, SEERI Correspondence Course on Syrian Christian Heritage 1, Kottayam, St. Ephrem Ecumenical Research Institute 1988, p. 17-22. At p. 7 he speaks of the "remarkably uniform text", i.e. the proto-Masoretic text.

51 Michael P. Weitzman, The Syriac Version of the Old Testament: An Introduction, Cambridge, Cambridge University Press 2005, p. 60. 
also a Syriac translation of the Septuagint (the Syro-Hexapla), but this happened later, between 614-616 A.D., being made by a certain Paul of Tella in Alexandria of Egypt, but whose circulation was limited. ${ }^{52}$

The important fact for the present discussion is that Peshitta was the Bible used by St. Ephrem the Syrian (306-373) and by St. Isaac the Syrian (c. 613 - c. 700), the future bishop of Nineveh in the Nestorian Assyrian Church of the East who was canonized as saint in the Greek Orthodox Church. In other words, two saints of the Orthodox Church, whose feast day falls on January 28, used a Bible translation based on a Vorlage which followed the Masoretic Text, rather than the Septuagint.

\section{The Prophetologium}

The Prophetologium appeared in Constantinople, in the context of liturgical reform around Stoudios Monastery, in the $8^{\text {th }}-9^{\text {th }}$ centuries. The manuscripts dated from the $9^{\text {th }}$ to $16^{\text {th }}$ centuries, with the peak in the $11^{\text {th }}-13^{\text {th }}$ centuries, but then the Prophetologium dissipated into other liturgical books (Menaia, Triodion and Pentecostarion).

Worth noting is the text contained in the Prophetologium. Basically, it is the Septuagint, but for the book of Daniel, the readings are taken from the recension of Theodotion, as St. Jerome had already observed in the $4^{\text {th }}$ century. I tried to track down a specific manuscript preeminence in the Prophetologium and therefore I compared the text of Judges $6 .{ }^{53}$

\begin{tabular}{|c|c|c|}
\hline $\begin{array}{c}\text { Septuagint } \\
\text { (Alexandrinus) }\end{array}$ & $\begin{array}{l}\text { Septuagint } \\
\text { (Vaticanus) }\end{array}$ & Prophetologium \\
\hline 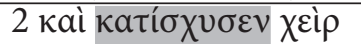 & 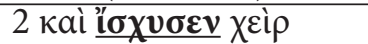 & 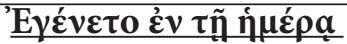 \\
\hline 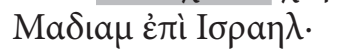 & 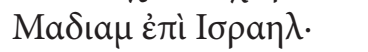 & 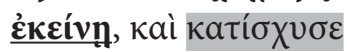 \\
\hline 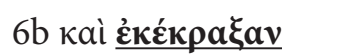 & 6b kaì દ̇ßór & Ėંì toùc \\
\hline 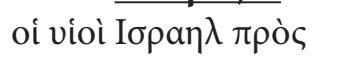 & 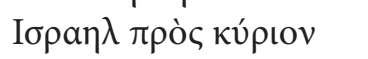 & $\underline{\text { vioi }}$ \\
\hline кúpiov. & 11 Kaì $\tilde{\eta} \lambda \theta \varepsilon v \stackrel{\alpha}{\gamma} \gamma \gamma \varepsilon \lambda \circ \varsigma$ & Kaì $\underline{\alpha}$ \\
\hline 11 Kaì $\tilde{\eta} \lambda \theta \varepsilon v$ ö $\gamma \gamma \varepsilon \lambda o c$ & 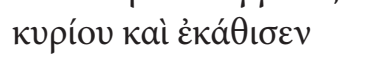 & \\
\hline kupíov & 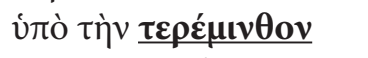 & Kaì î́ \\
\hline 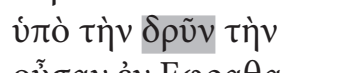 & 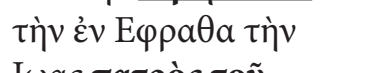 & 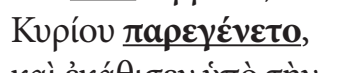 \\
\hline 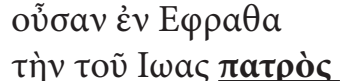 & 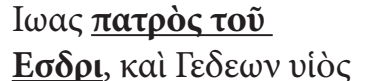 & 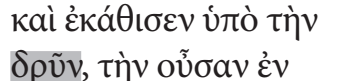 \\
\hline$\underline{A \beta \iota \varepsilon \zeta \rho \mathrm{L}, ~ \kappa \alpha i ̀ ~ Г \varepsilon \delta \varepsilon \omega v ~ \delta ~}$ & 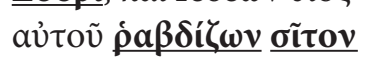 & 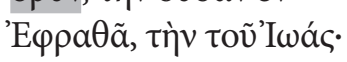 \\
\hline 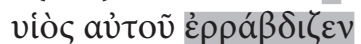 & $\dot{\varepsilon} \nu \lambda \eta \nu \tilde{\omega} \varepsilon \dot{\varepsilon l \varsigma} \varepsilon \dot{\varepsilon} \kappa \varphi v \gamma \varepsilon \tilde{\varepsilon} \nu$ & 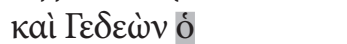 \\
\hline
\end{tabular}

\footnotetext{
52 S. P. Brock, The Bible, p. 14.

53 The table is taken from A. Mihăilă, "Lecțiuni biblice la sărbătorile sfinților în Paremiar", in: Studii Teologice, III series, 13 (3/2017), forthcoming.
} 


\begin{tabular}{|c|c|c|}
\hline 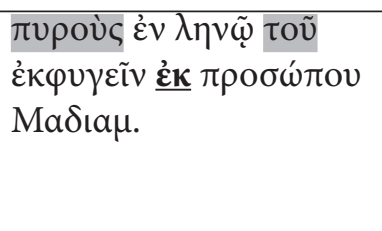 & 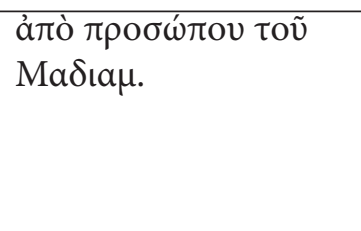 & 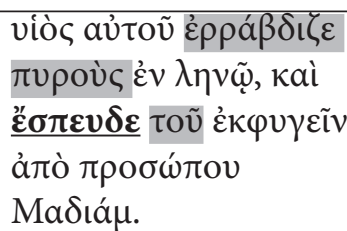 \\
\hline 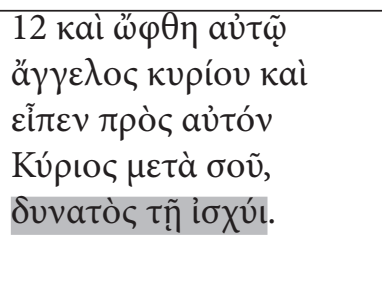 & 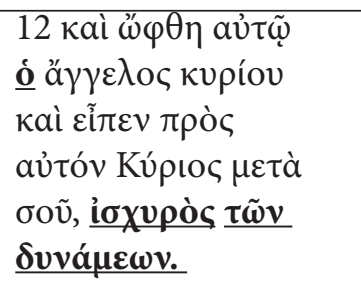 & 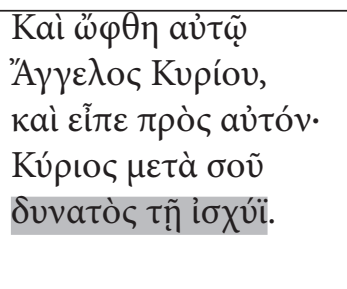 \\
\hline 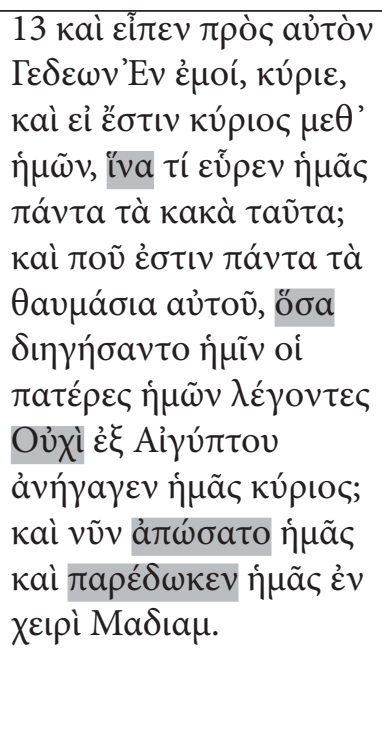 & 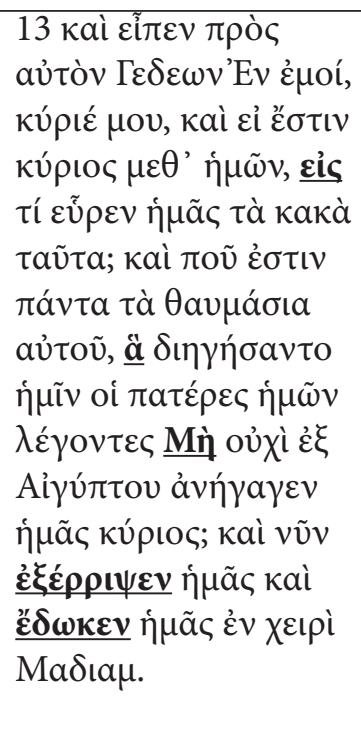 & 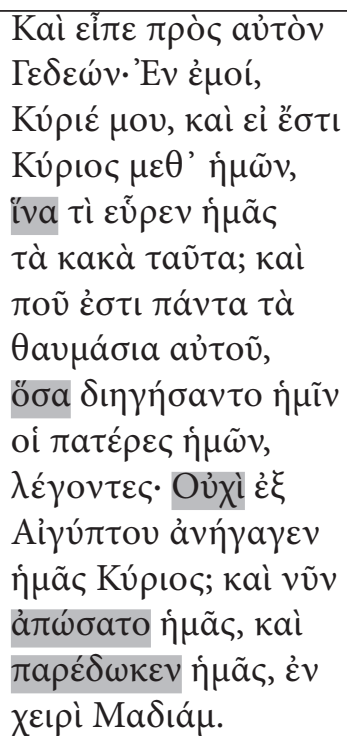 \\
\hline 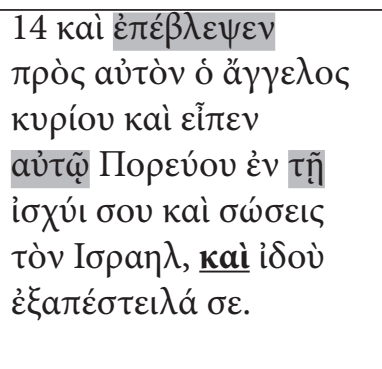 & 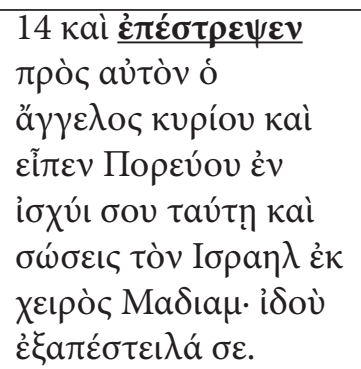 & 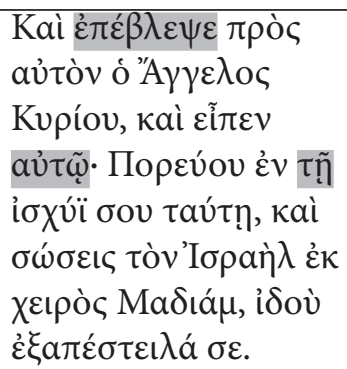 \\
\hline
\end{tabular}




\begin{tabular}{|c|c|c|}
\hline 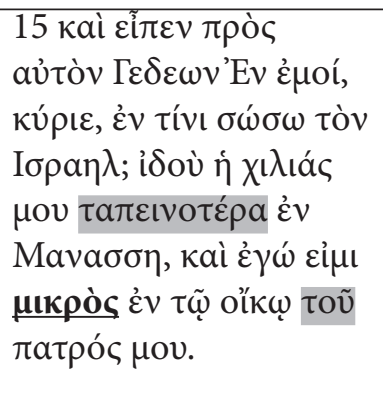 & 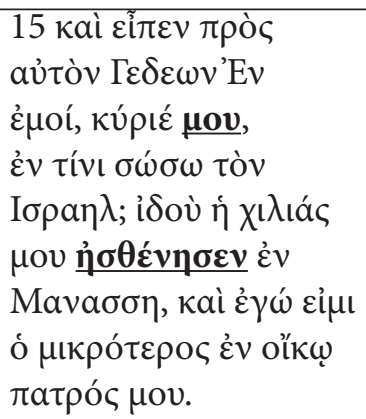 & 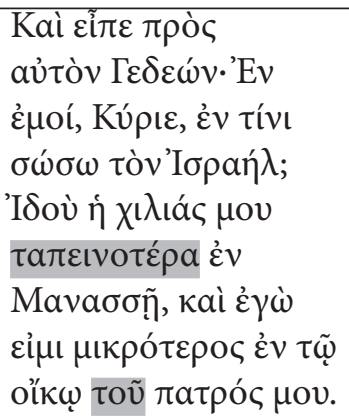 \\
\hline 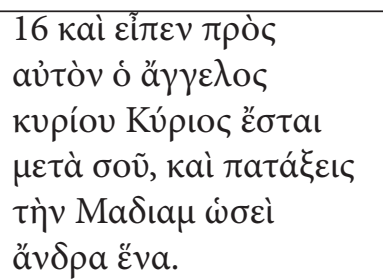 & 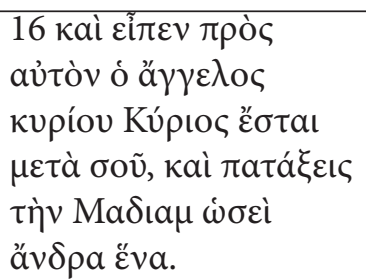 & 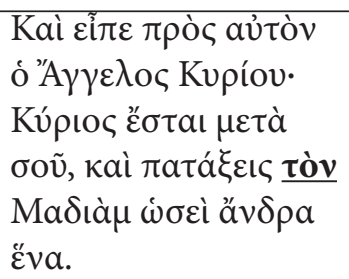 \\
\hline 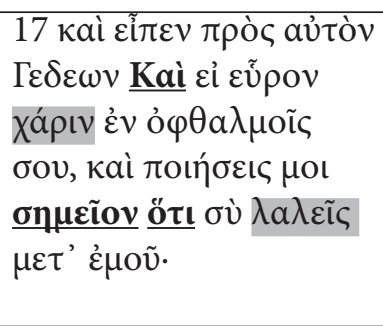 & 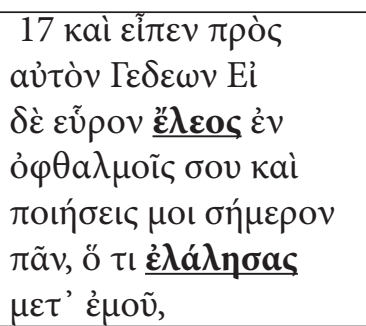 & 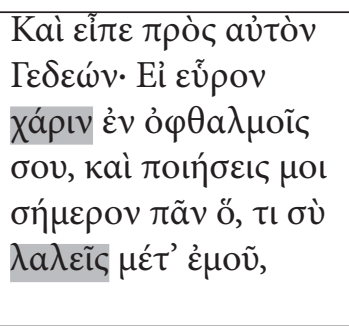 \\
\hline 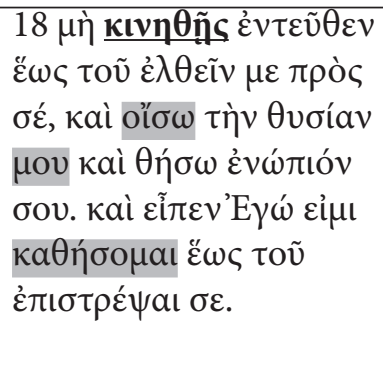 & 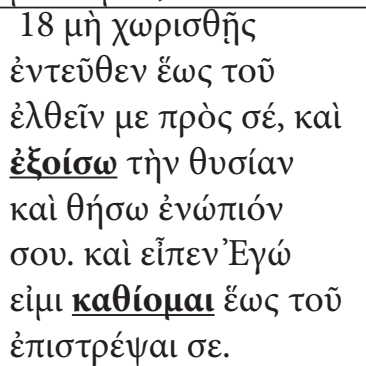 & 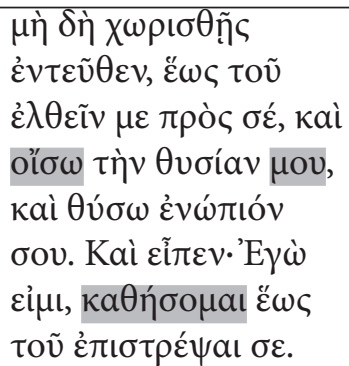 \\
\hline 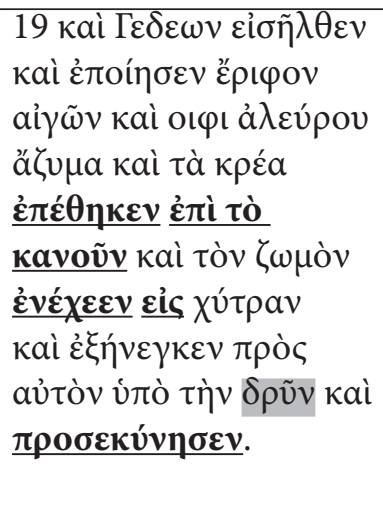 & 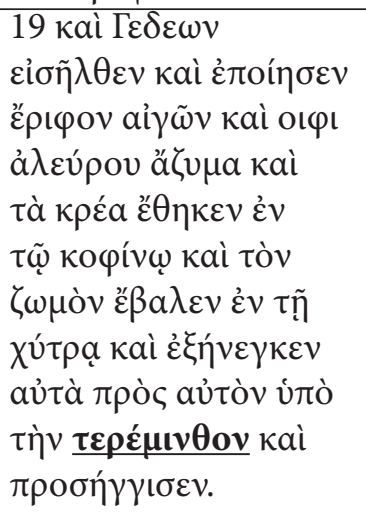 & 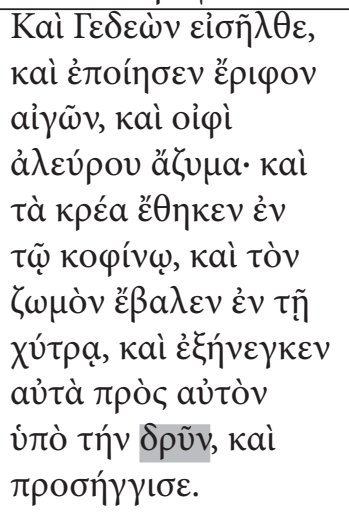 \\
\hline
\end{tabular}




\begin{tabular}{|c|c|c|}
\hline 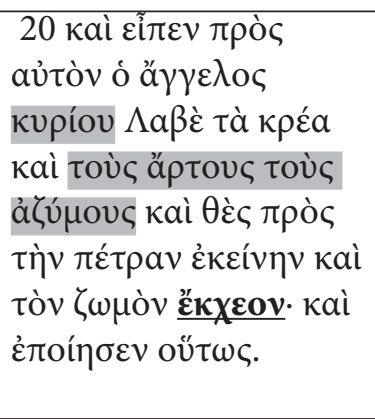 & 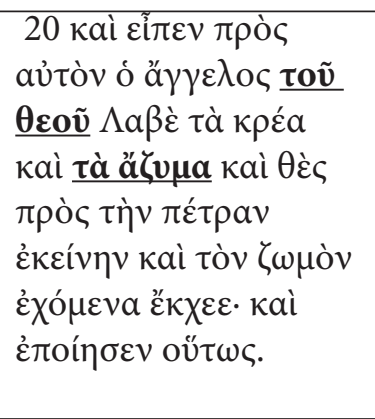 & 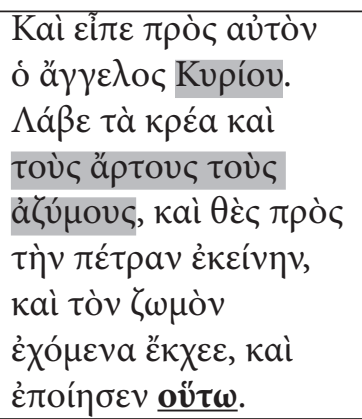 \\
\hline 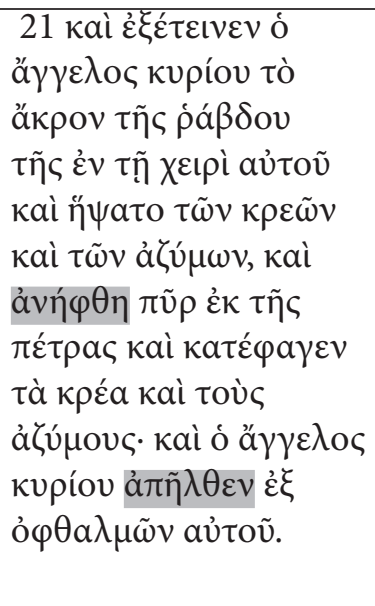 & 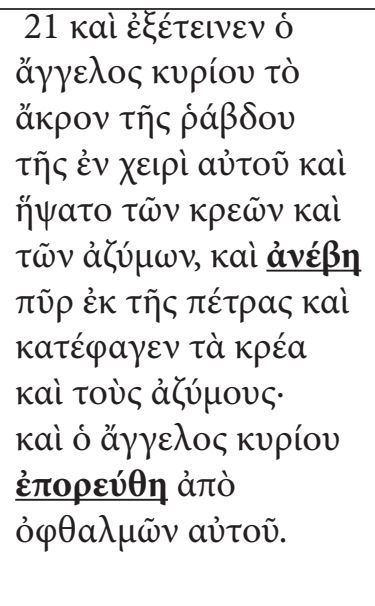 & 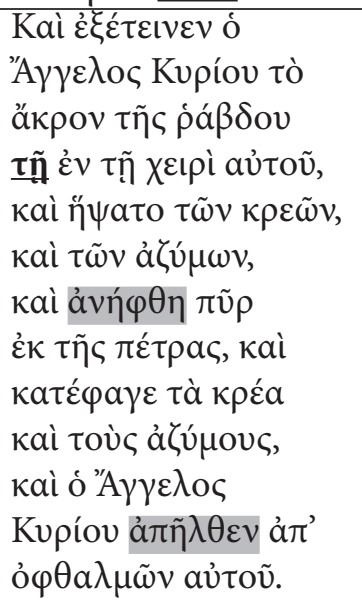 \\
\hline 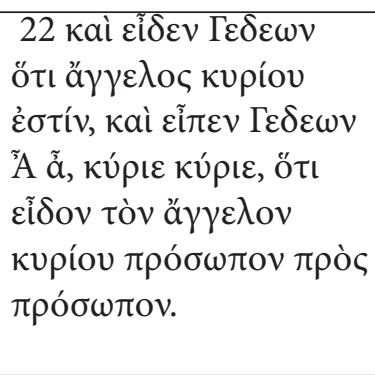 & 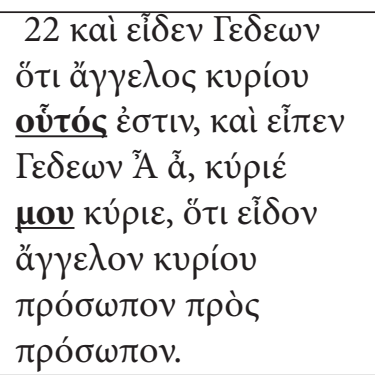 & 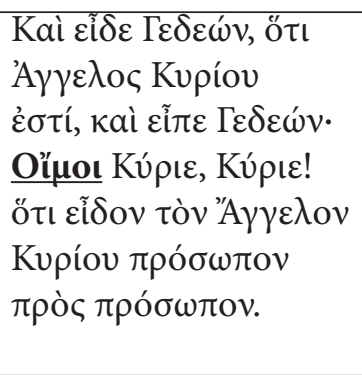 \\
\hline 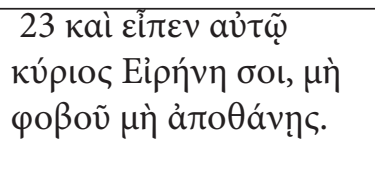 & 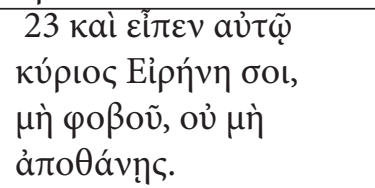 & 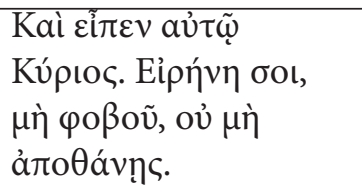 \\
\hline 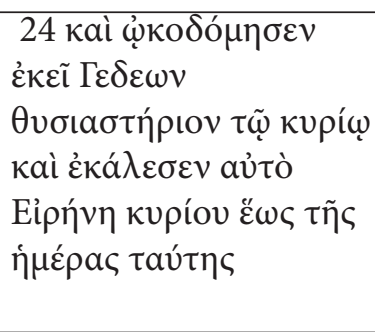 & 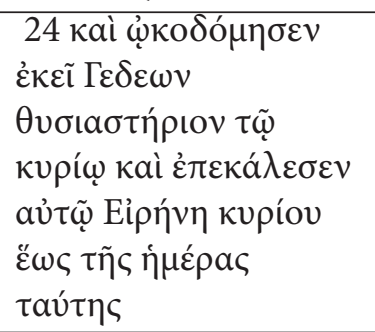 & 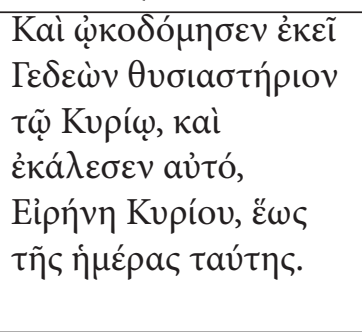 \\
\hline
\end{tabular}


As seen from the above table, the text of the Prophetologium doesn't follow any manuscript and thus it is an eclectic text. I highlighted with grey the cases where the text of the Prophetologium coincides with the text of the Codex Alexandrinus and with cassette the cases where the text of the Prophetologium coincides with the text of the Codex Vaticanus. Readings without parallel were marked with boldface and underlined. The cases of agreement between Prophetologium and Codex Alexandrinus (28) were slightly more numerous than the cases of agreement with the Codex Vaticanus (18).

In conclusion, the Orthodox Church doesn't use exclusively the Septuagint for the Old Testament lections. On the contrary, by combining different text variants she doesn't canonize any version or manuscript of the Septuagint.

\section{The $19^{\text {th }}$ century in the Orthodox Churches}

After 1000 A.D., the Orthodox Church and the Synagogue existed as two relatively isolated communities, because that was required in the Byzantine Empire on the part of non-Orthodox or non-Christian communities (Jews, Armenians, Arabs). Unlike the medieval West, in the East with few exceptions there were no anti-Jewish persecutions. Besides, in Byzantium there was a specific Jewish community of the so-called Romaniotes ${ }^{54}$, which even adopted the Greek language in religious services.

The first contacts with the Masoretic Text occurred in Russia, initially in heretical circles. By the end of the $15^{\text {th }}$ century, Judaizers appeared in the Novgorod area and then spread to Moscow, boasting among their leading figures the Moscow-born scribe Ivan Cherny. ${ }^{55}$ Although the Judaizers were harshly persecuted, being burnt at the stake in the years 15041505, their corrections made to the Slavonic text of the Old Testament, especially to the Pentateuch, were later integrated into the Ostrog Bible (1581), the first complete Scripture printed anywhere in the Orthodox milieu, and subsequently even into the Moscow Slavonic Bible (1663). The revisions were removed from the Elisabeth Bible $(1751)^{56}$, the current Slavonic edition used in the Russian Church. Nevertheless, these Judaizing corrections, which made their way into the Slavonic text, are all the more

54 Elli Kohen, History of the Byzantine Jews: A Microcosmos in the Thousand Year Empire, Lanham, University Press of America 2007.

55 Francis J. Thomson, “The Slavonic Translation of the Old Testament”, in: Jože Krašovec (ed.), The Interpretation of the Bible: The International Symposium in Slovenia, Journal for the Study of the Old Testament, Supplement Series 289, Sheffield, Sheffield Academic Press 1998, p. 605-920. At p. 651, he mentions that Cherny was a priest.

56 F.J. Thomson, “The Slavonic Translation”, p. 654. 
interesting, given the fact that the Slavonic Bible was initially indebted to the Septuagint.

\section{St. Nicodemus the Hagiorite and the Pedalion}

The Pedalion is a canonical collection compiled and interpreted by St. Nicodemus the Hagiorite (1749-1809). Because at that time Greece was under Turkish occupation and church books could not be published, it was printed in Leipzig, in 1800. In 1809 St. Nicodemus died, but the Pedalion went through multiple editions: 1841 (second edition), 1886 (fourth edition), 1908 (fifth edition). The Pedalion (from the Greek term for "rudder") serves as a canonical guide for the Orthodox Church, portrayed as the boat of Christ by the suggestive front-page lithography. Remarkably, in 1791, before being printed, this canonical compilation received the endorsement of the patriarchal synod of Constantinople.

In the commentary appended to the apostolic canon 85 which lists the biblical canonical books ${ }^{57}$, St. Nicodemus argues that the Jews have tampered with the Hebrew text. He brings some examples, found for example in St. Justin Martyr (Dialogue with Trypho), to prove that there are irreconcilable differences between the Septuagint and the Hebrew text. The Targums, the Aramaic paraphrases of the Hebrew text, seem to be more valued than the Hebrew text itself, which is not mentioned among the Scripture textual witnesses, although it remains as the source indicated for all the versions presented. There are only five important editions of the Bible: "the Greek, the Syriac, the Arabic, the Chaldaic and the Roman (Latin)".

The Greek translations of Aquila, Symmachus and Theodotion are "not unnecessary" (å $v \omega \varphi \varepsilon \lambda \varepsilon \tilde{\varsigma} \varsigma$ ) and could be used, as some Fathers did,

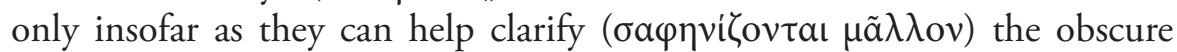
passages in the Septuagint. Along with the other versions, they are "useful"

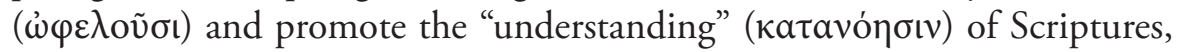
but should be employed with great care, because they have distorted certain messianic prophecies. The Peshitta is held in high regard for being very close to the Hebrew text and trustworthy, as is the Vulgate, St. Jerome's work, although it is not without errors. Could these errors be related to the use of the Vulgate by the Catholics? It is not specified.

The Septuagint itself is not without its shortcomings. The author notes that precisely a passage invoked by St. Justin in his dispute with Trypho as be-

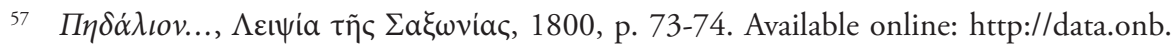
ac.at/ABO/\%2BZ182429704, viewed on 04/16/2018. I thank Father Filotheu (Bălan) for drawing my attention to this book. I compared it with the fourth edition, 'A $\theta \tilde{\eta} v a$, 1886, p. 101-103. For an English translation of the fifth edition, see: The Rudder, Pedalion, trans by. D. Cummings, Chicago, The Orthodox Christian Educational Society 1957, p. 150-152. 
ing omitted in the Hebrew text ("from the wood" in Psalm 96/95) cannot be found in the current editions of the Septuagint. St. Nicodemus also notes that the Church prefers Theodotion's translation of Daniel, because the Septua-

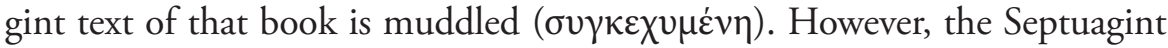
remains the edition of the Church. It is the only one considered authentic

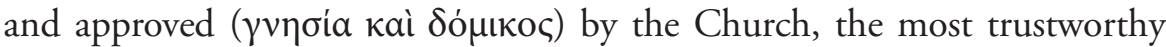

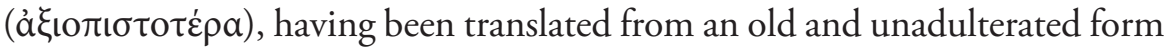
of the Hebrew text. The other versions are said to be neither approved nor

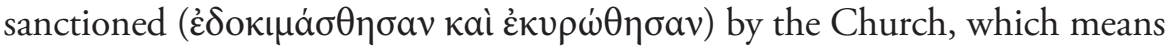
that the Septuagint is the only one which fulfills these conditions. That is why the Septuagint must take precedence over all the others.

Before moving on to the next theological figure, it should be noted that in 1848, The Encyclical of the Eastern Patriarchs (21), states something very similar: "Our Church holds the infallible and genuine deposit of the Holy Scriptures, of the Old Testament a true and perfect version, of the New the divine original itself" ${ }^{58}$ Although the letter does not mention any version explicitly, it takes little effort to realize that the Septuagint is in view.

Konstantinos Oikonomos and the controversy concerning the translation of the Bible into Modern Greek

Konstantinos Oikonomos (1780-1857) was not canonized by the Orthodox Church, but his scholarly output is substantial, as he wrote a monograph in four volumes about the Septuagint (1844-1849) ${ }^{59}$. He reacted to Neophytos Vamvas, archimandrite and professor at the National University of Athens, whose Bible translation into Modern Greek (katharevousa) became a cause célèbre soon after its inception in 1831. Vamvas' translation, commissioned by the British and Foreign Bible Society ${ }^{60}$ which required that the Hebrew text be used as Vorlage, was completed in 1851. However, the Holy Synod of the Church of Greece condemned it repeatedly when it was still a work in progress (i.e. in a letter dated 4 September 1834 to the ministry of educati-

58 https://sourcebooks.fordham.edu/halsall/mod/1848orthodoxencyclical.asp, viewed on $04 / 16 / 2018$.

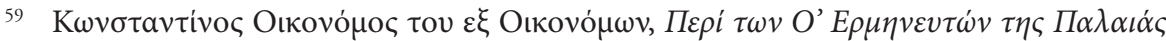

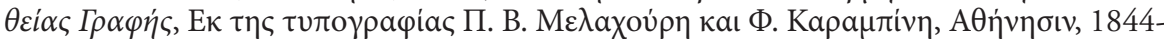
1849. Scanned copies of the volumes are available at http://anemi.lib.uoc.gr/metadata/8/b/6/ metadata-91-0000009.tkl. Volumes 2-4 are available, with a better resolution, at http://digital.lib.auth.gr/, viewed on 04/16/2018.

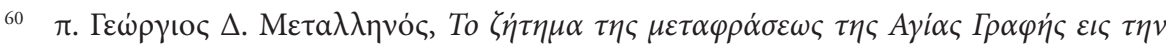

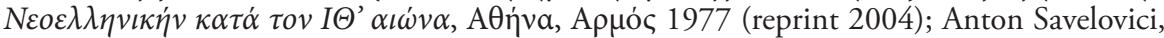
"Traducerea Sfintei Scripturi în neogreacă din sec. al XIX-lea la cererea și sub influența misiunilor protestante; versiunea lui Neofit Vamvas”, in: Studia Universitatis Babeș-Bolyai, Theologia Orthodoxa 55 (1/2010), p. 239-246. 
on, in a declaration issued on 2 February 1835 and in a special encyclical on 13 March 1836). ${ }^{61}$ Against this background, Oikonomos' monograph might be regarded as an erudite reaction to the spreading of a Bible translation based on the Masoretic Text. ${ }^{62}$

While in some respects Oikonomos' academic work was already outdated even by the standards of the $19^{\text {th }}$ century ${ }^{63}$, his erudition proved formidable ${ }^{64}$. He insisted on the inspiration of the Septuagint, giving credit to the ancient traditions about the origin of the translation in Alexandria under King Ptolemy II. In the fourth volume he made a synoptic comparison between the Hebrew Text (in Greek translation), the Septuagint and the New Testament quotations. From 238 cases listed by Oikonomos, only three or four could verify a source of the New Testament citation other than the Septuagint. ${ }^{65}$ Oikonomos' eulogy extolling the virtues of the Septuagint and his opposition to Bible translations into Modern Greek exerted an enormous influence in Greece, during the following century.

\section{St. Philaret (Drozdov) of Moscow and the Russian Synodal Bible}

The Masoretic text was, however, openly and officially accepted as a source in the synodal Russian translation. After a long period of turmoil which led to the abolition of the Russian Bible Society in 1826, Metropolitan Philaret (Drozdov) of Moscow (1782-1867) received the approval of Emperor Alexander II in 1856 to resume the translation process. The Holy Synod of the Russian Church accepted St. Philaret's view about the Bible translation from the original texts. In 1845 he had written an essay entitled "Concerning the dogmatic value and conserving function of the Greek Septuagint and the Slavonic translation of Holy Scripture", published only in 1858, when the enterprise seeking to render the Bible into Russian was in full swing ${ }^{66}$. The author argued that "the text of the Seventy interpreters should have a

${ }^{61}$ Athan Delicostopoulos, "Major Greek Translations of the Bible”, in: J. Krašovec (ed.), The Interpretation, p. 297-316 (here p. 313).

${ }^{62}$ Mark Siotes, "Constantine Oikonomos of the House of Oikonomos and the Operations of the British Bible Society in Greece (1780-1857)", in: Greek Orthodox Theological Review $6(1 / 1960)$, p. 7-55.

63 Abraham Wasserstein, David J. Wasserstein, The Legend of the Septuagint: From Classical Antiquity to Today, Cambridge, Cambridge University Press 2006, p. 259-260.

64 Evangelia G. Dafni, "Konstantinos Oikonomos ex Oikonomon als Septuaginta-Interpret”, in: André Lemaire (ed.), Congress Volume Ljubljana 2007, Supplements to Vetus Testamentum 133, Leiden - Boston, Brill 2010, p. 265-292.

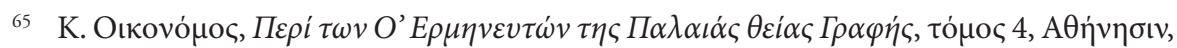
1849, p. 305-355.

66 S.K. Batalden, Russian Bible Wars, p. 123. 
dogmatic dignity (догматическое достоинство), in some cases equaling the original and even surpassing the Hebrew text" (I). ${ }^{67}$ There is, however, something to be said in favor of the Hebrew text:

The respect for the text of the Seventy interpreters should not be so excessive that the text of the Hebrew is given no consideration. Justice, usefulness and necessity (справедливость, польза и необходимость) require that the Hebrew text, in respect of dogmatic dignity (также въ догматическомъ достоинствъ) too, might be taken into consideration when interpreting the sacred Scripture (II).

A few passages of the Hebrew text are under suspicion, from among which the Jews found their advantage for disputes with the Christians; therefore, one should clearly refute the exclusive attachment (исключительную привязанность) to the Hebrew text and acknowledge the dogmatic importance of the text of the Seventy; but this does not provide a basis for rejecting the use of the Hebrew text. Even if a little distorted or suspected of damage, such passages of the Hebrew text are known and refuted, and therefore not dangerous to the scholar. But it is a friend of many places (другія многія мъста) which the Jews did not have to modify and, if not doubtful, can be used favorably, and sometimes, if necessary, should be taken into consideration when interpreting the Holy Scripture (II.1).

In 1856, his fierce opponent, St. Metropolitan Philaret (Amfiteatrov) of Kiev, had sent him a letter in defense of the Slavonic Bible. ${ }^{68} \mathrm{He}$ argued that the Jews "out of hatred of Christianity, have zealously tampered with the Hebrew text, especially in the prophetic books", whereas the Apostles and the Church used the Septuagint. He then concluded that "from the first centuries our Mother, the Eastern-Greek Church, has constantly recognized the translation of the Seventy, together with the original text of the New Testament, as sacred and inviolable (священнымъ и неприкосновеннымъ)". ${ }^{99} \mathrm{How}-$

67 Синодальнаго члена, Филарета, Митрополита Московскаго, “О догматическомъ достоинствъ и охранительномъ употребленіи греческаго седмидесяти толковниковъ и славенскаго переводовъ Священнаго Писанія", Прибавленія къ изданію твореній Святыхъ Отиевъ, въ русскомг переводъ, 17 (1858), p. 452-484. Available at http://biblia. russportal.ru/index.php?id=history.philaret01, viewed on 04/16/2018.

68 Stephen Batalden, "The BFBS Petersburg Agency and Russian Biblical Translation, 1856-1875", in: Stephen Batalden et al. (eds.), Sowing the Word: The Cultural Impact of the British and Foreign Bible Society 1804-2004, Sheffield, Sheffield Phoenix Press 2004, p. 169196 (here p. 177-178).

69 Составлено въ трехъ томахъ архимандритомъ Сергіемъ (Василевскимъ), Bbl сокопреосвященный Филаретъ, въ схимонашествьь Өеодосій (Амфитеатровъ), 
ever, St. Philaret of Moscow's view prevailed over St. Philaret Amfitreatov's opposition and the Russian Synodal Bible was published in 1876.

St. Theophan the Recluse and the controversy concerning the translation of the Bible into Russian

As a reaction to the completed translation of the Bible in Russian, St. Theophan the Recluse (1815-1894), former bishop of Vladimir and Suzdal, wrote a series of articles reviewing the new translation. He opined that "the pure revealed word (чистое богооткровенное слово) is contained in the Old Testament translation of the Seventy". It is true that sometimes, very rarely, saints such as St. John Chrysostom used the Hebrew text in order to explain obscure passages of the Septuagint and in that sense a Bible translation from the Hebrew might be used "as an accessory to the understanding of the true word of God (какъ пособіе къ уразумънію подлиннаго слова Божія)”, but generally the Mother Church "was not and is not acquainted with the Hebrew Bible (А она не знала и не знаетъ еврейской Библіи)". ${ }^{70}$

Professor Pavel Ivanovich Gorsky-Platonov (1835-1904), a Hebraist and biblical scholar teaching at Moscow Theological Academy, wrote an academic rejoinder. In his estimation, the differences between the Hebrew Text and the Septuagint amounted to 5\%. Such a low figure could not be a relevant argument against the validity of the Hebrew text. On the other hand, he stated that the Orthodox Church didn't recognize the Septuagint as the only "authentic revelation of the Old Testament" (подлиннъйшеe откровеніе ветхозавътное). ${ }^{71}$

St. Theophan answered, referring to Metropolitan Philaret's essay and to Oikonomos' monograph about the Septuagint. ${ }^{72}$ He recommended using the new Russian Synodal Bible just as the Fathers of the Church used other translations, giving precedence to the Slavonic Bible just as the Fathers had given pride of place to the Septuagint. He even noticed that sometimes the Russian Synodal Bible diverged from the Hebrew Text, as for example in Ps.

митрополитъ Кіевскій и Галицкій и его время, Типографія Окружнаго Штаба, Казань, volume 1, 1888, p. 459-512.

70 Епископъ Өеофанъ, “По поводу изданія книгъ Ветхаго Завъта въ русскомъ переводъ”, Душеполезное Чтеніе 11 (1875), р. 342-352.

71 П. И. Горскій-Платоновъ, “Нъсколько словъ о статьъ преосвященнаго епископа Өеофана: «По поводу изданія Священныхъ книгъ Ветхаго Завъта въ русскомъ переводъ»", Православное обозрпніе 3 (1875), p. 505-540. Available online: http://biblia.russportal.ru/index.php?id=history.gplatonov01, viewed on 04/16/2018.

72 Епископъ Өеофанъ, “О нашемъ долгъ держаться перевода 70-ти толковниковъ”, Душеполезное Чтеніе, 1876, nо. 5, p. 3-21. Available online: http://biblia.russportal.ru/ index.php?id=history.theophan02, viewed on $04 / 16 / 2018$. 
21.17, where the Septuagint is followed. But sometimes the Russian Bible followed the Hebrew text, as in Gen. 2.2, against the Slavonic Bible (and the Septuagint). The Synodal Bible represents neither the Hebrew text, nor the Septuagint, but a combination of the two (сочетанія той и другой).

He states that the Holy Synod did not ascribe to the Russian Bible "the significance of dogmatic authority (значенія догматическиавторитетнаго)". The only Bible credited with dogmatic authority was the Septuagint. Therefore, "the Bible in the new translation can be revered as a book for reading, education and instruction (почитаема книгою для чтенія, многоназидательною и многополезною), but is in no way the Bible, clothed with dogmatic authority (догматическимъ авторитетомъ)." 73 He considered the Septuagint to be the "legitimate" (законная) Bible and the "authentic" (подлиннъйшій) text of the Old Testament of the Orthodox Church, because the Hebrew text is "corrupt"। (поврежденъ). ${ }^{74}$

\section{Can the Septuagint stand alone, isolated from the Hebrew Text?}

Before drawing the conclusions, another question should be raised. Can the Septuagint stand alone, isolated from the Hebrew Text? Rev. Eugen J. Pentiuc quotes Marguerite Harl and states the following: "In other words, the Septuagint may be employed with no relation whatsoever to the MT."75

I will give two examples illustrating the effect of ignoring the Hebrew text while translating the Septuagint. In Judg. 5.7 (Codex Alexandrinus) $\varphi \rho \alpha \dot{\zeta} \zeta \omega v$ is just one of several cases when the Septuagint resorted to transliteration for lack of a better solution. Without consideration of the Hebrew Text (פרזון), a translator of the Septuagint would confuse it with the participle of Greek $\varphi \rho \alpha \dot{\zeta} \omega \omega$. This actually happened in the Romanian Septuagint translation under the auspices of New Europe College: the translator rendered it "there was no one to utter a word in Israel" ("n-a fost cine să spună cuvânt în Israel"). ${ }^{76}$ The second example was already mentioned above: in

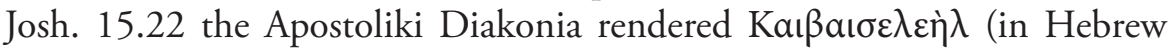

\footnotetext{
73 Епископъ Өеофанъ, “Объ употребленіи новаго перевода ветхозавътыхъ писаній”, Душеполезное Чтеніе, 1876, no. 3, p. 100-106. Available online: http://biblia. russportal.ru/index.php?id=history.theophan06, viewed on 04/16/2018.

74 Епископъ Өеофанъ, “Библія по переводу Семидесяти толковниковъ есть законная наша Библія”, Домашняя беспда 19 (1876), р. 499-503, 527-529, 555-559, 579-582. Available online> http://biblia.russportal.ru/index.php?id=history.theophan04, viewed on $04 / 16 / 2018$.

75 E.J. Pentiuc, The Old Testament, p. 70.

76 C. Bădiliță et al. (ed.), Septuaginta, volume II: Iisus Nave, Judecători, Ruth, 1-4 Regi, Iași, Colegiul Noua Europă - Polirom 2004, p. 138.
} 


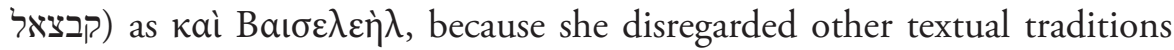
besides the Septuagint.

The team who produced the New English Translation of the Septuagint adopted a different view: although "the Septuagint in time achieved its independence from its Semitic parent, [...] for the vast majority of books the linguistic relationship of the Greek to its Semitic parent can best be conceptualized as a Greek interlinear translation of a Hebrew original within a Hebrew-Greek diglot" ${ }^{77}$ I argue that the above examples, as well as many others, favor this kind of understanding.

\section{Conclusions}

In the article dedicated to the "Bible" in The Encyclopedia of Eastern Orthodox Christianity, Theodore Stylianopoulos wrote: "The Orthodox Church holds to the Greek Septuagint version of the Old Testament in its wider canon as the authoritative text". ${ }^{78}$ The information is simplistic both in respect to the text of the Scripture and to its canon. But can we formulate a satisfactory conclusion so far? Studying the evidence, I really got the impression of walking on quicksand.

As a fitting conclusion, I will quote two texts written by the same person, Metropolitan Hilarion Alfeyev of Volokolamsk, President of the Synodal Biblical and Theological Commission of the Russian Orthodox Church. The first text was published in 2012, the second one in 2013. Given the nature of the topic, perhaps a biblical caveat is not altogether out of place: $\delta$

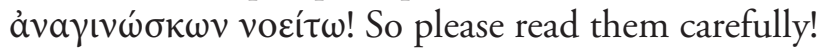

While all of the canonical books of the Old Testament are written in Hebrew, the basis of the Old Testament text in the Orthodox tradition is the Septuagint [...] The authority of the Septuagint is based on three factors. First of all, though the Greek text is not the original language of the Old Testament books, the Septuagint does reflect the state of the original text as it would have been found in the third to second centuries BCE, while the current Hebrew text of the Bible, which is called the 'Masoretic,' was edited up until the eight century CE. Second, some of the citations taken from the Old Testament and found in the New mainly use the Septuagint text. Third, the Septuagint was used by both the Greek Fathers of the Church, and Orthodox liturgical services (in other words,

\footnotetext{
77 "To the Reader of NETS", in: Albert Pietersma, Benjamin G. Wright (eds.), A New Translation, p. xiv.

78 Theodore G. Stylianopoulos, "Bible”, in: John Anthony McGuckin (ed.), The Encyclopedia of Eastern Orthodox Christianity, volume 1, Malden, Wiley-Blackwell 2011, p. 71.
} 
this text became part of the Orthodox Church Tradition). Taking into account the three factors enumerated above, St Philaret of Moscow considers it possible to maintain that in the Orthodox teaching of Holy Scripture it is necessary to attribute a dogmatic merit to the Translation of the Seventy, in some cases placing it on an equal level with the original and even elevating it above the Hebrew text, as is generally accepted in the most recent editions. If the Septuagint has served as a textus receptus (official, 'received' text) in the Eastern Church for many centuries, then the Vulgate [...] has been a comparable text for the Church in the West. ${ }^{79}$

The second one is a report published on the official website of the Russian Patriarchate.

It is very important for us that the Orthodox Church has never canonized any one text or translation, any one manuscript or one edition of Holy Scripture (Православная Церковь никогда не канонизировала какой-то один текст или перевод, какуюто одну рукопись или одно издание Священного Писания). There is no single generally accepted text of the Bible in the Orthodox tradition (Единого общепринятого текста Библии в православной традиции нет). There are discrepancies between quotes from the Scriptures of the Fathers; between the Bible adopted in the Greek Church and the Church Slavonic Bible; between Church Slavonic texts of the Bible and recommended for home reading by the Russian Synodal translation. These discrepancies should not embarrass us, because behind different texts in different languages, in different translations there is a single Good News. An especially important role (особо важную роль) for the Orthodox tradition is played by the ancient Greek translation of the Old Testament, the Septuagint, which was completed before Christ. This is due to the following factors. First, the Septuagint can be used to recreate the original Old Testament text in places where errors have crept into the standard Jewish (so-called Masoretic) text. Secondly, many quotations from the Old Testament in the New Testament reflect the text of the Septuagint. Thirdly, it was the text of the Greek Bible that was used in the works of the Greek Fathers of the Church, and in the liturgical texts of the Orthodox Church.

It is not true, however, to assert that it is the Septuagint and only the Septuagint that is the Bible of Orthodoxy (Неверно, однако,

79 Metropolitan Hilarion Alfeyev, Orthodox Christianity, volume 2: Doctrine and Teaching of the Orthodox Church, New York, St Vladimir's Seminary Press - Yonkers 2012, p. 34. 
было бы утверждать, что именно Септуагинта и только

Септуагинта является Библией Православия). ${ }^{80}$

Can we ask in earnest what the Orthodox think about the relation between the Septuagint and the Masoretic Text? The argument of authority turned out to be not much help, because different ecclesiastic authorities (saints, holy synods) gave different answers, sometimes opposing each other, but at the same time meant to represent the Orthodox tradition.

I tried to crosscheck the coherence of Orthodox positions and discovered that although the Bible is conceived of as a source of divine revelation, the Orthodox Churches do not have a consistent approach toward the text of the Old Testament. They are incapable of saying if they have indeed an official text or a manuscript. The approach toward the Hebrew Text is also inconsistent: it is allowed in ecclesiastical and academic use and even has its dogmatic importance, but on the opposite side, it is not worthy to be mentioned as a textual witness, due to its alleged corruption by the Jews.

As is often the case, the periphery tends to be more conservative than the center. This might explain why the Antiochian Orthodox from America sponsored a translation from the Septuagint, while in Greece the translation blessed by the Church follows the Hebrew Text and, on the other hand, Bartolomeu Anania’s Romanian translation couldn't replace the Romanian Synodal Bible, which combines the Hebrew and the Greek texts. The Synodal Bibles of both Russian and Romanian Churches represent a compromise between the Septuagint and the Hebrew Text. The conservative approach specific to the periphery could also explain why monastic circles are wholly devoted to the Septuagint and disregard the Hebrew Text, which grew up in a separate community, perceived as hostile.

One might predict increasing traditionalistic approaches in the Orthodox Churches. It would be interesting to observe if one of the non-Greek churches, the Russian or the Romanian Church, will adopt as a (permanent) synodal version a translation of the Septuagint.

80 http://www.patriarchia.ru/db/text/3394042.html, viewed on 04/16/2018. 